\title{
Webbed penis: A rare case
}

\section{Agrawal R', Chaurasia $\mathbf{D}^{2}$, Jain $\mathbf{M}^{3}$}

${ }^{1}$ Resident in Surgery, ${ }^{2}$ Associate Professor, Department of Urology, ${ }^{3}$ Assistant Professor, Department of Plastic and Reconstructive Surgery, MLN Medical College, Allahabad (India)

\begin{abstract}
Webbed penis belongs to a rare and little-known defect of the external genitalia. The term denotes the penis of normal size for age hidden in the adjacent scrotal and pubic tissues. Though rare, it can be treated easily by surgery. A case of webbed penis is presented with brief review of literature.
\end{abstract}

Key words: penis, webbed

$\mathrm{W}$ ebbed penis is a rare anomaly of structure of penis. Though a congenital anomaly, usually the patient presents in late childhood or adolescence. Skin of penis forms the shape of a web, covering whole or part of penis circumferentially; with or without glans, burying the penile tissue inside. The length of shaft is normal with normal stretched length. Phimosis may be present. The penis appears small without any difficulty in voiding function.

\section{Case report}

Our patient, a 17 year old male, presented to us with congenital webbed penis. On examination, skin webs were present on both lateral sides from prepuce to lateral aspect of penis.[Fig. 1] On ventral aspect, the skin web was present from prepuce to inferior margin of median raphe of scrotum. Thus, skin webs were enclosing penis just like webs on toe of a duck. Shaft of penis was normal in size. Voiding was normal and phimosis was absent. There were no other developmental anomaly in the patient.

Surgery was performed via Z-plasty on anterior aspect and a transverse incision in middle of $Z$ converting it in double Z-plasty.[Fig. 2] Patient remained well after 2 months of follow up. There was no problem in erection or voiding.

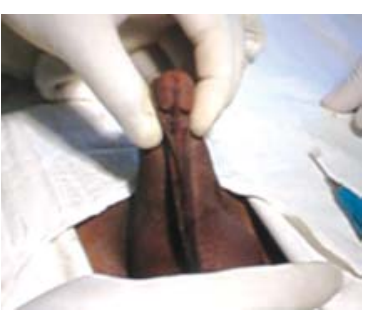

Fig 1: Penis showing web of skin on anterior aspect

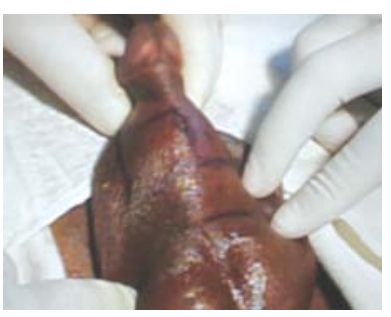

Fig 2: Markings for double Z-plasty on penis

\section{Discussion}

Webbed penis is a developmental malformation with less than 60 cases reported in literature. The term denotes the penis of normal size for age hidden in the adjacent scrotal and pubic tissues.

Rudin and Osipova ${ }^{1}$ presented the largest series on webbed penis. They described 30 boys of webbed penis along with their clinical symptoms, anatomicalmorphological features underlying development of this entity, proposed the classification including three basic clinical forms of this malformation, and outlined the principles of diagnosis and differential diagnosis with the conditions associated with a small-size penis. They also provided surgical management and techniques in each form of the disease with adjustment for anatomic features. 
Abbate et $\mathrm{al}^{2}$ gave a comprehensive review of 92 patients with penile anomalies excluding hypospadias. The reported incidence was $9.78 \%$ ( 9 patients) for webbed penis.

Bergeson et $\mathrm{al}^{3}$ found one case of webbed penis and one case of combined webbed and buried penis among 19 patients of inconspicuous penis. Both were repaired surgically without any complications.

Amano et $\mathrm{al}^{4}$ reported a case of phimosis with webbed penis in an 11-year old boy with recurrent epididymitis. They operated by transverse incision followed by longitudinal suture and dorsal incision for true phimosis.

Medina Lopez et $\mathrm{al}^{5}$ reported a case of webbed penis associated with phimosis and penile curvature. Treatment offered to this patient was Z-plasty and circumcision. We performed double Z-plasty with good results.

Lynch and Bushby ${ }^{6}$ reported a new syndrome associated with congenital emphysema, cryptorchidism, a penoscrotal web, deafness, constipation and mental retardation. However, this is not proved in any other study. Our patient has duck-toe penis only and was free from any other disease.

Alter ${ }^{7}$ performed augmentation phalloplasty with Zplasty in a patient with penoscrotal web with good results.

Hara and Kanamori ${ }^{8}$ treated a case of webbed penis by dorsal incision.

Shepard et $\mathrm{al}^{9}$ found only 10 previous reported cases. They reported case of a 1-year old boy and repaired it by a rectangular scrotal flap to close the penoscrotal junction and multiple $\mathrm{W}$-plasty incisions for closure of the skin of the shaft of the penis successfully.

Webbed penis is a rare condition that can be treated easily by surgery with good results.

\section{References}

1. Rudin IuE, Osipova AI. Experience of surgical treatment of webbed penis in children. Urologiia. 2003;2: 36-41.

2. Abbate B, Danti DA, Pancani S, Pampaloni A. Congenital anomalies of the penis in children. A few consideration about 92 cases. Minerva Pediatr. 1994; 46: 139-42.

3. Bergeson PS, Hopkin RJ, Bailey RB Jr, McGill LC, Piatt JP.The inconspicuous penis. Pediatrics. 1993; 92: 794-9.

4. Amano T, Kobori Y, Matsushita T, Takemae K. Recurrent epididymitis in a boy with a webbed penis without chordee: a case report. Hinyokika Kiyo. 2004; 50: 737-9.

5. Medina Lopez RA, Campoy Martinez P, Jimenez del Valle U, Hernandez Soto R, Ramirez Mendoza A, Soltero Gonzalez A.The webbed penis. A report of a new case. Arch Esp Urol. 1999; 52: 68-9.

6. Lynch SA, Bushby KM. Congenital emphysema, cryptorchidism, penoscrotal web, deafness, and mental retardation--a new syndrome? Clin Dysmorphol. 1997; 6: 35-7.

7. Alter GJ. Augmentation phalloplasty. Urol Clin North Am. 1995; 22: 887-902.

8. Hara M, Kanamori S. A case of webbed penis. Hinyokika Kiyo. 1987 33: 951-2.

9. Shepard GH, Wilson CS, Sallade RL: Webbed penis. Plast Reconstr Surg. 1980; 66: 453-4. 